\title{
Predestinasi
}

Volume 13, No. 2, Juni 2020, Hal. 61- 66

ISSN (Print): 1978-9351

\section{Covid 19 Natural Evil / Human Evil: A Philosophical Investigation}

\author{
Uzommah Michael $^{1}$, Anselm Ikenna Odo ${ }^{2}$, Nwohah Petermary ${ }^{3}$ \\ ${ }^{1}$ Department Of Philosphy, Albertine Institue, Fayit Fadan Kagoma, \\ Via Kafanchan, Kaduna State, Nigeria \\ ${ }^{2}$ Department of Educational Foundations,,, Philosophy of Education Unit \\ Nasarawa State University, Keffi, Nigeria \\ ${ }^{3}$ Department Of Philosophy and Religious Studies \\ Tansian University, Umunya Anambra State, Nigeria \\ *e-mail: uzomahmichaelabuchi@yahoo.com, anselmikenna4us@gmail.com, \\ pito4us@gmail.com.
}

\begin{abstract}
This paper sought to find out whether COVID 19 is as a result of natural evil, human evil or both. The researchers adopt an expository method in carrying out this work. Viruses have been around in the world long as life itself. We can confidently say that life as we know it would not exist without viruses. Viruses do leave "fossils" in the Deoxyribonucleic Acid (DNA)-the hereditary material in humans and of other organisms, from which their history can be reconstructed. It is as a result of this that the researchers posit that COVID 19 is neither natural evil nor human evil. The researchers conclude that the issue of COVID 19 outbreak ravaging the earth has a sufficient reason. But sometimes our emotions blind us from seeing the reason but solely the event.
\end{abstract}

Keywords: natural evil; human evil; COVID 19.

\section{INTRODUCTION}

It is a noticeable phenomenon that the ugly situation facing the world today is the explosion of COVID 19 pandemic. Which many scholars and layman relegate it to the problem of evil. Some viewed it as a result of punishment from God; some sees it to be consequence of human evil. This necessitates asking; how do we reconcile the existence of evil in the world with a good and loving God? When evil happens to us personally or to those we love, the most pressing question might be something like, "why us God not protecting us from this evil that is amongst us? That is usually more like an existential cry of the heart than a philosophical puzzle to be solved. Why would God create a world like this, where this coronavirus can wreak such havoc on our daily lives, and even kill people by hijacking their respiratory systems?

Analyzing the question, it is worthy to note that people can do evil things. This is a direct consequence of free will. And the world is a better place because there are humans with free will, even though they sometimes use it for evil purposes. Notable, COVID 19 is different; this is because 'free will' defense does not work for viruses. They are not intentional agents that make decisions or have moral responsibility. They just do what they are programmed to do. In that 


\author{
$62 \mid$ Predestinasi \\ Volume 13, No. 2, Desember 2020 Hal. 61- 66
}

regard, it warrants us to wonder why God create these things and program them to devastate like this. However, the researchers are on the opinion that the COVID 19 (Coronavirus) pandemic; does not take long for serious questions about evil and suffering to arise rather it is something that has been into existence before man.

\title{
CLARIFICATION OF TERMS
}

\section{COVID 19}

According to WHO (2020) Coronavirus disease 2019 (COVID-19) is an infectious disease caused by severe acute respiratory syndrome coronavirus 2 (SARS-CoV-2) (Umukoro et al., 2020; Udok et al., 2020). On the other hand, Hui et al (2020) stated that the disease was first identified in December 2019 in Wuhan, the capital of China's Hubei province, and has since spread globally, resulting in the ongoing 2019-20 coronavirus pandemic (Bassey 2020; Bassey \& Eуо 2020).

The World Health Organization (WHO) declared the 2019-20 coronavirus outbreak a Public Health Emergency of International Concern (PHEIC) on 30 January 2020 and a pandemic on 11 March 2020.Local transmission of the disease has been recorded in many countries across all six WHO regions.

The World Health Organization announced in February 2020 that COVID-19 is the official name of the disease. World Health Organisation chief Tedros Adhanom Ghebreyesus explained that CO stands for corona, VI for virus and D for disease, while 19 is for when the outbreak was first identified: 31 December 2019. The name had been chosen to avoid references to a specific geographical location (e.g. China), animal species or group of people, in line with international recommendations for naming aimed at preventing stigmatisation. The virus that causes COVID19 is named severe acute respiratory syndrome coronavirus 2 (SARS-CoV-2). The WHO additionally uses "the COVID-19 virus" and "the virus responsible for COVID-19" in public communications. Coronaviruses were named in 1968 for their appearance in electron micrographs which was reminiscent of the solar corona, corōna meaning crown in Latin. Both the disease and virus are commonly referred to as "coronavirus".

\section{SIGNS AND SYMPTOMS OF COVID 19}

Signs and symptoms of corona virus include:

1. Fever

2. Cough and shortness of breath

3. Fatigue,

4. Muscle pain

5. Diarrhea

6. Sore throat

7. Loss of smell and

8. Abdominal pain.

However, the time from exposure to onset of symptoms is typically around five days, but may range from two to 14 days. While the majority of cases result in mild symptoms, some progress to viral pneumonia and multi-organ failure. As of 9 April 2020, more than 1.48 million cases have been reported in more than 200 countries and territories, resulting in more than 88,600 deaths. More than 331,000 people have recovered. 


\section{MODES OF TRANSMISSION}

The virus is mainly spread during close contact and by small droplets produced when those infected cough, sneeze or talk. These droplets may also be produced during breathing; however, they rapidly fall to the ground or surfaces and are not generally spread through the air over large distances. People may also become infected by touching a contaminated surface and then their face. The virus can survive on surfaces for up to 72 hours. Coronavirus is most contagious during the first three days after onset of symptoms, although spread may be possible before symptoms appear and in later stages of the disease.

\section{PREVENTIVE MEASURES}

To prevent the spread of Covid 19, it is expected you clean your hands often. Use soap and water, or an alcohol-based hand rub.

Maintain a safe distance from anyone who is coughing or sneezing.

Wear a mask when physical distancing is not possible.

Don't touch your eyes, nose or mouth.

Cover your nose and mouth with your bent elbow or a tissue when you cough or sneeze.

Stay home if you feel unwell. If you have a fever, cough and difficulty breathing, seek medical attention.

Facemask: always wear face/nose masks. Masks can help to prevent the spread of the virus from the person wearing the mask to others.

\section{EFFECT OF CORONA VIRUS TO A NATION}

Covid 19 has rapidly affected our day to day life, businesses, disrupted the world trade movements. It is worthy of note that the early identification of the disease is vital and easy to control. The spread of the virus vary rapidly spreads from person to person. Most countries have slowed down their manufacturing of the products. The various industries and sectors are affected by the cause of this disease; these include the pharmaceuticals industry, solar power sector, tourism, Information and electronics industry (Asira \& Francis 2012). Going further, Haleem, Vaishya and Javaid (2020) noticed that the virus creates significant knock- on the daily life citizens, as well as about the global economy.

Without doubt, the effects of corona virus pandemic have reach extensively in our daily life activities and have developed far reaching consequences. Thus:

\section{Health care}

In the issue of diagnosis, quarantine and treatment of suspected or confirmed cases have being a great challenge. It has lead to the burden of the functioning of the other existing medical system. This has also led to the negligence of patients with other diseases and health problems. It has added more loads to the Doctors and other healthcare professionals, who are at a very high risk. Overloading of medical shops is noticed, which requires a high protection.

\section{Economic}

Economically, covid 19 pandemic has resulted the slowing down of the manufacturing of essential goods. It has led to the losses of national and international businesses. It also affects poor cash flow in the market. It also necessitated the significant of slowing down in the revenue growth.

\section{Social}




\author{
64| Predestinasi \\ Volume 13, No. 2, Desember 2020 Hal. 61- 66
}

Covid 19 has resulted the improper service sectors in various fields for instances, it has caused the cancellation or postponement of large -scale sports and tournament. Avoiding the national and international traveling and cancellation of services has being observed as a result of social challenge towards covid 19 pandemic. It has caused disruption of celebration and celebration of cultural, religious and festive events, postponement of examinations. Social distancing with our peers and family members and closure of places for entertainment such as movie and play theatres, sports clubs, gymnasiums, swimming pools, and so on has also contributed an impact of covid 19 pandemic.

This covid 19 has affected the sources of supply and affects the global economy. There are restrictions of traveling from one country to another country. During traveling, numbers of cases are identified positive when tested, especially when they are taking international visits (Chinazzi, Davis and Ajelli, 2020).

\title{
Natural evil
}

Natural evil is the evil in the world that arises from what we call "natural" events, things that are the result of the way the world operates. This would include earthquakes, floods, tornadoes, disease, birth defects, and other aspects of our world that cause suffering and death. It causes pain and suffering to humanity but which is not direct to human involvement.

\section{Human evil}

Human evil is the evil that is caused by human activity such as murder, rape, robbery, embezzlement, hatred jealousy etc. It occurs when people choose to act in defiance of God's law. Human evil is the evil that emanate from man based on his activities that are not logically coherent with the ideal of human behavior. It is an act of wickedness. Human evil is as a result of man's inhumanity to man. It can also be referred to as the dehumanization of a man.

\section{COVID 19 neither natural evil nor human evil: A justification}

Justifying the COVID 19 pandemic as neither natural evil nor human evil; the researchers outlined the following point using virus relevance to back up their stands. However, Covid 19 outbreak has caused more harm than good globally in the life of every citizen. Notwithstanding, deducing from the role of viruses in the humans, plant and animals, one can say that COVID 19 was a great threat to human life because it was not control/ checkmate ab initio. Although, deducing from this, viruses can serve as:

\section{Bacteria checker}

Praveen Sethupathy cited by $\operatorname{Jim}$ (2020) opines that the population of viruses on Earth is estimated to be $10,000,000,000,000,000,000,000,000,000,000$. That is a really big number (1031)-ten billion times more stars than there are in the universe! What are they all doing? It is noticed that the vast majority of them are not infecting humans, but rather they are infecting bacteria and keeping them in check.

There are about the same number of bacteria on Earth as there are viruses. In our bodies alone, each of us has about 100,000,000,000,000 individual bacteria. That is about ten times more bacterial cells than human cells in our bodies!

\section{Digestive processor}


They provide all kinds of useful functions for us, particularly for our immune system and indigestion. It is safe to say that life as we know it would not work without them. But they have a tendency to take over, if left unchecked.

For example, E. coli bacteria reproduce every 20 minutes under ideal conditions. So if you start with one bacterium, in 20 minutes there will be two, and in forty minutes there will be four, and at one hour there will be eight. If that went on unchecked, by the end of one twenty-four-hour day, the population would double 72 times, which is close to $5 \times 1021$, and if you let that go on for a year, it is a number so big I am pretty sure that is more bacteria than the mass of the Earth.

So, it is very good that the overwhelming majority of viruses on Earth are infecting bacteria and slowing down their reproduction. And in order to keep doing that effectively, viruses have to keep mutating. So every once in a while, a virus will appear that can infect and do harm to humans. Taking away that possibility, though, would make it impossible for us to live. Just like earthquakes and tornadoes, viruses sometimes cause harm, suffering, and death. But without them, we cannot conceive of how life would be possible. In addition, Pope cited by Cindy (200) opines that COVID 19 is not God's judgment on humanity, but God's call on people to judge what is most important to them and resolve to act accordingly from now on. He further says it is not time of our judgment: a time to choose what matters and what passes away, a time to separate what is necessary from what is not. For example, viruses are a living being it is up to be checkmating it before it causes more harm than good to us. That is why Dirk (2020) observed that the more common Ribonucleic acid (RNA) viruses-like the coronaviruses behind the current pandemic-have typically smaller genome sizes than Deoxyribonucleic acid (DNA) virus, apparently because of higher error-rate when replicating. Too many errors have the effect that natural selection disfavors them. It also limits maximum size of these viruses.

This seems to support the hypotheses that life originated with a Ribonucleic acid (RNA) world, and that for very primitive life Ribonucleic acid (RNA) to worked perfectly fine to pass on genetic information. As organisms grew in size they required larger genomes and needed to transfer more information. At that point DNA outcompeted RNA as a type of informational code. But Ribonucleic acid (RNA) survives as an essential part of terrestrial biology, as we are seeing with the coronavirus SARS-CoV-2.

\section{Genetic transfer}

Viruses also have benefits. Most of the genetic information on Earth probably resides within them, and viruses are important for transferring genes between different species, increasing genetic diversity and ultimately enhancing evolution and the adaptation of various organisms to new environment challenges. When life was first arising on Earth, they may have been critical to evolution of the first cells.

\section{Product of natural evolution}

Evolution is a change in the genetic composition of a population over a successive generation. According to Andersen (2020) COVID-19 more closely resembles strains of coronavirus found in bats and pangolins. The features changes in the Receptor Binding Domain (RBD) portion of the spike protein and its distinct backbone, rules out laboratory manipulation as a potential origin for SARS-CoV-2.That is to say that COVID-19 spike protein is so efficient at binding to human cells that it could only be a result of natural selection, not artificial engineering (https://www.labmate-online.com/news/laboratory-products/3/breaking-news/is-covid-19-manmade-or-natural/51980) 
66 Predestinasi

Volume 13, No. 2, Desember 2020 Hal. 61- 66

\section{Progammed entity}

Notable, COVID 19 is different; this is because 'free will' defense does not work for viruses. They are not intentional agents that make decisions or have moral responsibility. They just do what they are programmed to do.

\section{CONCLUSION}

From the philosophical investigation so far, the issue of COVID 19 outbreak ravaging the earth has a sufficient reason. But sometimes our emotions blind us from seeing the reason but solely the event. Without doubt, majority of the human race is focused on the virus, its effects and how to survive not some bigger picture of "why the virus? Or "some futuristic good purpose" we are sure finding a vaccine is the big purpose right now for humanity and we really hope it is available soon so this too shall pass and we go back to daily lives.

\section{REFERENCES}

Anderson (2020). Covid 19-man made or natural? Retrieved from https://www.labmateonline.com/news/laboratory-products/3/breaking-news/is-covid-19-man-made-ornatural $/ 51980$

Asira, A. E., \& Francis, E. (2012). Religious appraisal of the human concept in world religions. American Journal of Social Issues \& Humanities, 2(2), 65-72.

Bassey, S. A. (2020). Technology, Environmental Sustainability and the Ethics of Anthropoholism. Przestrzeń Społeczna, 1, 19.

Bassey, S. A., \& Eyo, U. E. (2020). Covid-19 Outbreak: Wet Markets and the Ethics of Anthropoholism. Euromentor, 11(3).

Chinazzi, M., Davis, J.T and Ajelli, M (2020). The effects of travel restrictions on the spread of the 2019 novel coronavirus (covid 19) outbreak. Science 2020doi:10.1126/

Cindy, W. (2020). COVID-19 is not God's judgment, but a call to live differently, pope says. Retrieved from https://www.thebostonpilot.com/amp_article.asp?ID=187257) 3/27/2020.

Dirk, S. (2020). There are more viruses on earth than there are stars in the universe. Retrieved from https://www.airspacemag.com/daily-planet/there-are-more-viruses-earth-tere-arestars-universe-180974433/

Haleem, A., Javaid, M., Vaishya, R (2020). Effects of covid-19 pandemic in daily life. Retrieved from https://www.ncbi.nlm.nih.gov/pmc/articles/PMC714720/

Udok, M. B., Eton, C. U., \& Akpanika, E. N. (2020). Coronavirus pandemic and its effect on African religiosity. International Journal of Humanities and Innovation (IJHI), 3(3), 109114.

Umukoro, G. M., Odey, V. E., \& Yta, E. M. (2020). The Effect of Pandemic on Homebased Tourism: Post Covid-19. International Journal of Humanities and Innovation (IJHI), 3(3), $115-120$ 